\title{
C:N:P stoichiometry as indicator of Histosol drainage in lowland and mountains forest ecosystem
}

Jarosław Lasota ( $\sim$ rllasota@cyf-kr.edu.pl)

University of Agriculture in Krakow: Uniwersytet Rolniczy im Hugona Kollataja w Krakowie

Ewa Błońska

Univeristy of Agriculture in Krakow

Research

Keywords: dehydration, forest soils, lowland, mountain, peat soils

Posted Date: December 28th, 2020

DOI: https://doi.org/10.21203/rs.3.rs-135014/v1

License: () (i) This work is licensed under a Creative Commons Attribution 4.0 International License. Read Full License 


\section{Abstract \\ Background}

Peatlands form one of the largest carbon pools in the terrestrial biosphere, representing approximately one-third of the world's soil carbon. The aim of this study is to establish and compare the C/N/P ratio of different types of Histosols. We believe that C/N/P stoichiometry is a good indicator of changes occurring in Histosols, especially those caused by dehydration. Four types of Histosols from lowland and mountain areas were investigated: fibric Histosols, hemic Histosols, sapric Histosols and Histosols drainic.

\section{Results}

We established the concentration and stoichiometry of carbon, nitrogen and phosphorous in the Histosols, and found marked differences in C/N/P stoichiometry between the different types - especially the dehydrated samples. The average C/N/P ratio of dehydrated soil was narrower than the C/N/P ratio of soil under the influence of water, which demonstrates that dehydrating Histosols leads to a narrower C/N/P stoichiometry. This is directly related to the intensification of the organic matter mineralisation process and the resulting loss of organic carbon. We recorded a $50 \%$ lower carbon stock in the case of Histosols drainic compared to the other types of Histosols.

\section{Conclusions}

The narrower $\mathrm{C} / \mathrm{N} / \mathrm{P}$ stoichiometry in Histosols drainic is the result of an improvement in the ratio of $\mathrm{N}$ and $\mathrm{P}$ to the $\mathrm{C}$ content. Thus, this study demonstrates that C/N/P stoichiometry is a useful indicator of the changes that occur in Histosols as a result of dehydration.

\section{Introduction}

The issue of organic carbon accumulation is commonly discussed in current scientific research. Soil is the most important reservoir of carbon in its cycle. It is estimated that carbon contained in soils constitutes $75 \%$ of the world's entire organic carbon stock, and that there is twice as much carbon stock in the soil than there is in the atmosphere (Farquhar et al. 2001). Increasing carbon stocks in terrestrial ecosystems is a useful tool for the restriction of carbon dioxide emissions into the atmosphere and for combatting climate change (Dorrepaal et al. 2009; Fornara et al. 2011). Among terrestrial ecosystems, forest ecosystems contain the highest levels of organic carbon accumulation. In these ecosystems, organic carbon is accumulated in the biomass of trees, shrubs, and herbaceous plants and in the soil profile. Peatlands form one of the largest carbon pools in the terrestrial biosphere, representing approximately one-third of the world's soil carbon (Waddington and Price 2013). Peat degradation, which is conducive to climate change, comes from the drainage of peatlands (Joosten 2009), fires (Yallop and Clutterbuck 2009) and conversion for agriculture (Carlson et al. 2013). The level of organic carbon accumulation in soil depends on a variety of factors. One of the most important is the quality of the site conditions - the soil humidity (Zwydak et al. 2008), type of vegetation, and management method (Kondras et al. 2012; Leifeld et al. 2020), in particular. A common cause for forest site degradation is a change in hydrological conditions, which occurs as a result of natural processes or human activities and involves vast areas of forests, primarily in lowland areas (Kabała and Marzec 2016). In dehydrated areas, an intensive aeration of the surface horizons occurs, which leads to increased mineralisation, and thus, an increase in the organic matter decomposition rate (Błońska and Lasota 2017). Peat soils comprise approximately $10 \%$ accumulated organic material (carbon) and $90 \%$ water. When this water is removed through drainage, the carbon in the peat soil is exposed to aerobic conditions, which leads to decomposition of the peat and emission of $\mathrm{CO}_{2}$ into the atmosphere. It has been estimated that drained peatlands in the temperate zone can lose between 1 to $2 \mathrm{~cm}$ of height per year, but with year-round high temperatures driving higher rates of peat decomposition, the rate can be as high as 3 to $5 \mathrm{~cm}$ per year. Approximately $45 \%$ of peatland has been drained, and this drained peat emits about $25 \%$ of the total $\mathrm{CO}_{2}$ emissions (Slepetiene et al. 2018). 
Common international names for the soils formed in organic soil material are: Histosols, peat soils, muck soils, bog soils or organic soils. According to WRB (2014), Histosols are soils that contain more than a particular defined quantity of organic soil materials. Histosols are found at all altitudes, but the vast majority occur in lowlands. The degree of organic matter decomposition of Histosols is an important diagnostic criterion. In Poland, peatlands cover $12547 \mathrm{~km}^{2}$ - most of this area is situated in the northern part of the country; peatlands tend to occur less frequently towards the south (Ilnicki 2002).

As basic components, carbon, nitrogen and phosphorus play an important role in the study of the nutrient cycle and the structure and function of the ecosystem (Sterner and Elser 2002). C, N and P are the basis of primary circulation and they regulate the aboveground community composition as well as the processes that take place within the soil itself (Huang et al. 2018). According to Fang et al. (2019), understanding the spatial patterns and drivers of plant and soil stoichiometry is key to improving the parameterisation of future ecological models and predicting ecosystem responses to environmental change. Until now, the $\mathrm{C} / \mathrm{N}$ ratio has most often been used to characterise soil organic matter (Tipping et al. 2016), while less attention has been paid to phosphorus, which is considered to be one of the most important regulators of the carbon and nitrogen cycle in organic soils (Zhang et al. 2017).

Understanding the processes of organic matter accumulation in forest ecosystems remaining in a state of ecological balance or in a state of disturbed homeostasis is particularly important for understanding the $\mathrm{C}, \mathrm{N}$ and $\mathrm{P}$ cycle in the natural environment. Despite the increasing number of studies on the carbon cycle, knowledge of the dynamics of its transformation in a degraded environment as a result of drainage remains limited. The aim of our research is to present the amount of $C, N$ and $P$ in different Histosols subtypes. We believe that C/N/P stoichiometry is a good indicator of changes occurring in Histosols, especially those caused by dehydration. In this study we examine samples from lowlands and mountain sites from the temperate zone of a forest in Poland to infer whether ratios of $\mathrm{C} / \mathrm{N}, \mathrm{C} / \mathrm{P}$ and $\mathrm{P} / \mathrm{N}$ are good indicators of the element content of Histosols. We hope that a better understanding of the mechanisms and factors that influence the dynamics of carbon, nitrogen and phosphorus in forest Histosols will allow for intentional creation of these phenomena in the future, which will contribute to preventing the negative effects of climate change, especially drainage.

\section{Materials And Methods}

\section{Study area}

One hundred and two plots of Histosols distributed throughout Poland in lowland (86 study plots) and mountainous (26 study plots) areas were selected for the study (Fig. 1). Four types of Histosols were investigated: fibric Histosols, hemic Histosols, sapric Histosols and Histosols drainic. The sapric Histosols contained less than one-sixth recognisable plant tissue after the material was gently rubbed, while the fibric Histosols contained more than two-thirds recognisable plant tissue (after rubbing); hemic Histosols were intermediate, with amounts that landed between fibric and sapric peat. For the Histosols drainic, the surface horizons were artificially drained. In the lowlands, the Histosols drainic were represented by 21 plots, the fibric Histosols by 25 plots, the hemic Histosols by 21 plots, and the sapric Histosols by 19 plots. In the mountains, the drainic Histosols were represented by 9 plots, the fibric Histosols by 3 plots, the hemic Histosols by 6 plots, and the sapric Histosols by 8 plots. Fibric Histosols are associated with communities of coniferous species, while acidophilic species dominate in the undergrowth. In the case of hemic Histosols, we found the communities to be richer, and the stands are mixed with pine, spruce, birch and alder. Stands on sapric Histosols consist of various species of alder, and the undergrowth vegetation is very diverse, with the participation of species requiring fertile soil rich in nutrients (Table 1).We dug a soil pit on each research plot, and we separated the soil horizons. Furthermore, we took samples from each horizon for further analysis. 
Table 1

Characteristics of vegetation on research plots

\begin{tabular}{|c|c|c|c|}
\hline Localization & $\begin{array}{l}\text { Type of } \\
\text { Histosol }\end{array}$ & Plant community & Dominant undegrowth species \\
\hline \multirow[t]{4}{*}{ Lowland } & $\begin{array}{l}\text { H. } \\
\text { drainic }\end{array}$ & $\begin{array}{l}\text { Molinio-Pinetum, Betuletum } \\
\text { pubescentis }\end{array}$ & $\begin{array}{l}\text { Molinia caerulea, Dryopteris dilatata, Calamagrostis arundinacea, } \\
\text { Juncus effusus, Juncus conglomeratus }\end{array}$ \\
\hline & fibric $\mathrm{H}$. & Vaccinio uliginosi-Pinetum & $\begin{array}{l}\text { Sphagnum sp., Vaccinium uliginosum, Ledum palustre, Oxycoccus } \\
\text { palustris }\end{array}$ \\
\hline & $\begin{array}{l}\text { hemic } \\
\text { H. }\end{array}$ & Sphagno squarrosi-Alnetum & $\begin{array}{l}\text { Sphagnum sp., Thelypteris palustris, Carex canescens, Peucedanum } \\
\text { palustre }\end{array}$ \\
\hline & $\begin{array}{l}\text { sapric } \\
\text { H. }\end{array}$ & Ribeso nigri-Alnetum & $\begin{array}{l}\text { Lucopus europaeus, Carex elongata, Scirpus sylvaticus, Iris } \\
\text { pseudacorus }\end{array}$ \\
\hline \multirow[t]{4}{*}{ Mountain } & $\begin{array}{l}\text { H. } \\
\text { drainic }\end{array}$ & $\begin{array}{l}\text { Abieti-Piceetum, } \\
\text { Calamagrostio villosae- } \\
\text { Peceetum }\end{array}$ & $\begin{array}{l}\text { Vaccinium myrtillus, Dryopteris dilatata, Dryopteris carthusiana, } \\
\text { Luzula sylvatica, Calamagrostis villosa }\end{array}$ \\
\hline & fibric $\mathrm{H}$. & $\begin{array}{l}\text { Calamagrostio villosae- } \\
\text { Piceetum }\end{array}$ & $\begin{array}{l}\text { Sphagnum sp., Vaccinium myrtillus, Oxycoccus palustris, Galium } \\
\text { hercynicum }\end{array}$ \\
\hline & $\begin{array}{l}\text { hemic } \\
\text { H. }\end{array}$ & Bazzanio-Piceetum & Sphagnum sp., Bazzania trilobata, Juncus effusus, Carex nigra \\
\hline & $\begin{array}{l}\text { sapric } \\
\mathrm{H} \text {. }\end{array}$ & Caltho-Alnetum & $\begin{array}{l}\text { Caltha palustris, Chaerophyllum hirsutum, Valeriana simplicifolia, } \\
\text { Filipendula ulmaria, Chrysosplenium altenifolium }\end{array}$ \\
\hline
\end{tabular}

\section{Laboratory analysis of the soil samples}

After delivery to the laboratory, we dried and sieved (through $2.0 \mathrm{~mm}$ mesh) the soil samples obtained in the field. We analysed the $\mathrm{pH}$ of the samples using the potentiometric method, and we measured the carbon (C) and nitrogen $(\mathrm{N})$ contents with an elemental analyser (LECO CNS TrueMac Analyser) (Leco, St. Joseph, MI, USA). Total P was determined using inductively coupled plasma optical emission spectrometry (ICP-OES) (iCAP 6500 DUO, Thermo Fisher Scientific, Cambridge, U.K.) after prior mineralisation. A mixture of concentrated nitric and perchloric acids was used to mineralise the soil samples, and we performed the calculation of the $\mathrm{C} / \mathrm{N}, \mathrm{C} / \mathrm{P}$ and N/P ratios on a molecular level. The $\mathrm{C}, \mathrm{N}$ and $\mathrm{P}$ stoichiometry was calculated for the surface horizons of the tested soils. Moisture was expressed as percentage of weight and bulk density (Bd) was determined using $250 \mathrm{~cm}^{3} \mathrm{Kopecky}$ cylinders (Ostrowska et al. 1991).

The soil organic carbon stock $\left(\mathrm{C}_{\mathrm{S}}\right)$, nitrogen stock $\left(\mathrm{N}_{\mathrm{S}}\right)$ and phosphorus stock $\left(\mathrm{P}_{\mathrm{S}}\right)$ were calculated as a sum of their total content at particular soil horizons. In each of the analysed soils, the stock was calculated for a $1 \mathrm{~m}^{2}$ soil block area at a $100 \mathrm{~cm}$ depth from the surface. Stock up to $100 \mathrm{~cm}$ was treated as a total stock of organic carbon, and we calculated the stock for the particular depths by summing the $\mathrm{C}, \mathrm{N}$ or $\mathrm{P}$ stock at subsequent genetic soil horizons according to the formula:

$\mathrm{C}_{\mathrm{S}}=\mathrm{C}^{*} \mathrm{D} * \mathrm{~m}\left(\mathrm{Mg}^{\mathrm{h}} \mathrm{ha}^{-1}\right)$

$\mathrm{N}_{\mathrm{S}}=\mathrm{N}{ }^{*} \mathrm{D}^{*} \mathrm{~m}\left(\mathrm{Mg}_{\mathrm{ha}} \mathrm{h}^{-1}\right)$

$P_{S}=P * D * m\left(M g \cdot h a^{-1}\right)$

where $\mathrm{C}=$ organic carbon content at the subsequent genetic horizon (\%), $\mathrm{N}=$ nitrogen content at the subsequent genetic horizon (\%), $\mathrm{P}=$ phosphorus content at the subsequent genetic horizon (\%), Bd = bulk density $\left(\mathrm{g} . \mathrm{cm}^{-3}\right), \mathrm{m}=$ thickness of the horizons $(\mathrm{cm})$.

\section{Statistical analysis}

To assess differences between means for properties of Histosols, we used Tukey's HSD test. We used the principal components analysis (PCA) method to evaluate the relationships between soil properties and type of Histosol, and a general linear model (GLM) was used to investigate the effect of the type Histosol, localisation and moisture on carbon, nitrogen and phosphorus stock. All statistical analyses were performed with Statistica 10 software (2010). 


\section{Results}

The tested soils differed in both chemical properties and moisture (Table 1). Lower statistically significant levels of moisture were recorded for the Histosols drainic, regardless of the location of the research plots. Furthermore, the surface horizons of the tested soils differed in $\mathrm{pH}$. Sapric Histosols had the highest $\mathrm{pH}$, while fibric Histosols had the lowest, regardless of the location. The lowland area did not show any significant differences in carbon content between the different types of Histosols. Samples from the mountains, however, revealed a significantly higher $\mathrm{C}$ content in fibric Histosols. Histosols in the mountains showed no differences in $\mathrm{N}$ content; this is in contrast to the results from the lowlands, which revealed that the highest nitrogen content was recorded in the sapric Histosols (Table 2). Moreover, sapric Histosols had a significantly higher P content, both for the samples from the mountains and from the lowlands.

Table 2

Basic properties of soil in the first horizon

\begin{tabular}{|c|c|c|c|c|c|c|c|c|c|c|c|}
\hline Localization & $\begin{array}{l}\text { Type of } \\
\text { Histosol }\end{array}$ & $M$ & $\stackrel{\mathrm{pH}}{\mathrm{H}_{2} \mathrm{O}}$ & $\mathrm{pH}$ & C & $\mathbf{N}$ & $\mathbf{P}$ & $\mathrm{C} / \mathrm{N}$ & $\mathrm{C} / \mathrm{P}$ & N/P & C:N:P \\
\hline \multirow[t]{4}{*}{ Lowland } & H.drainic & $\begin{array}{l}40.86 \\
\pm \\
12.00^{b}\end{array}$ & $\begin{array}{l}4.62 \\
\pm \\
1.34^{\mathrm{b}}\end{array}$ & $\begin{array}{l}3.74 \\
\pm \\
1.37^{b}\end{array}$ & $\begin{array}{l}35.79 \\
\pm \\
16.60^{\mathrm{a}}\end{array}$ & $\begin{array}{l}1.54 \\
\pm \\
0.73^{\mathrm{bc}}\end{array}$ & $\begin{array}{l}0.05 \\
\pm \\
0.02^{b}\end{array}$ & $\begin{array}{l}27.7 \\
\pm \\
12.9^{\mathrm{b}}\end{array}$ & $\begin{array}{l}1895.0 \\
\pm \\
1116.7^{a}\end{array}$ & $\begin{array}{l}66.1 \\
\pm \\
24.0^{\mathrm{ab}}\end{array}$ & $1895: 66: 1$ \\
\hline & fibric $\mathrm{H}$. & $\begin{array}{l}82.21 \\
\pm \\
6.46^{a}\end{array}$ & $\begin{array}{l}3.65 \\
\pm \\
0.21^{c}\end{array}$ & $\begin{array}{l}2.88 \\
\pm \\
0.23^{c}\end{array}$ & $\begin{array}{l}39.08 \\
\pm 6.47^{a}\end{array}$ & $\begin{array}{l}1.11 \\
\pm \\
0.25^{c}\end{array}$ & $\begin{array}{l}0.05 \\
\pm \\
0.01^{b}\end{array}$ & $\begin{array}{l}41.6 \\
\pm \\
10.5^{a}\end{array}$ & $\begin{array}{l}2264.4 \\
\pm \\
579.7^{a}\end{array}$ & $\begin{array}{l}56.0 \\
\pm \\
14.2^{b}\end{array}$ & 2264:56:1 \\
\hline & hemic $\mathrm{H}$. & $\begin{array}{l}77.90 \\
\pm \\
6.20^{\mathrm{a}}\end{array}$ & $\begin{array}{l}4.45 \\
\pm \\
0.60^{\mathrm{b}}\end{array}$ & $\begin{array}{l}3.62 \\
\pm \\
0.66^{\mathrm{b}}\end{array}$ & $\begin{array}{l}41.51 \\
\pm \\
11.81^{\mathrm{a}}\end{array}$ & $\begin{array}{l}1.90 \\
\pm \\
0.62^{\mathrm{ab}}\end{array}$ & $\begin{array}{l}0.06 \\
\pm \\
0.02^{\mathrm{b}}\end{array}$ & $\begin{array}{l}26.0 \\
\pm \\
6.9^{\mathrm{bc}}\end{array}$ & $\begin{array}{l}2123.0 \\
\pm \\
1523.6^{a}\end{array}$ & $\begin{array}{l}79.5 \\
\pm \\
46.5^{a}\end{array}$ & 2123:80:1 \\
\hline & sapric H. & $\begin{array}{l}78.09 \\
\pm \\
6.04^{\mathrm{a}}\end{array}$ & $\begin{array}{l}5.90 \\
\pm \\
0.84^{\mathrm{a}}\end{array}$ & $\begin{array}{l}5.37 \\
\pm \\
1.01^{\mathrm{a}}\end{array}$ & $\begin{array}{l}32.21 \\
\pm 7.33^{\mathrm{a}}\end{array}$ & $\begin{array}{l}2.02 \\
\pm \\
0.47^{\mathrm{a}}\end{array}$ & $\begin{array}{l}0.11 \\
\pm \\
0.03^{\mathrm{a}}\end{array}$ & $\begin{array}{l}18.8 \\
\pm \\
3.4^{\mathrm{c}}\end{array}$ & $\begin{array}{l}796.9 \pm \\
327.6^{\mathrm{b}}\end{array}$ & $\begin{array}{l}42.4 \\
\pm \\
16.6^{b}\end{array}$ & 797:42:1 \\
\hline \multirow[t]{4}{*}{ Mountain } & H.drainic & $\begin{array}{l}44.02 \\
\pm \\
8.56^{\mathrm{b}}\end{array}$ & $\begin{array}{l}5.27 \\
\pm \\
1.36^{\mathrm{ab}}\end{array}$ & $\begin{array}{l}4.58 \\
\pm \\
1.32^{\mathrm{ab}}\end{array}$ & $\begin{array}{l}19.85 \\
\pm 8.90^{b}\end{array}$ & $\begin{array}{l}1.03 \\
\pm \\
0.44^{\mathrm{a}}\end{array}$ & $\begin{array}{l}0.05 \\
\pm \\
0.02^{b}\end{array}$ & $\begin{array}{l}23.5 \\
\pm \\
5.7^{a}\end{array}$ & $\begin{array}{l}986.8 \pm \\
339.3^{b}\end{array}$ & $\begin{array}{l}43.8 \\
\pm \\
17.5^{a}\end{array}$ & $987: 44: 1$ \\
\hline & fibric $\mathrm{H}$. & $\begin{array}{l}81.80 \\
\pm \\
7.45^{a}\end{array}$ & $\begin{array}{l}3.78 \\
\pm \\
0.22^{b}\end{array}$ & $\begin{array}{l}2.79 \\
\pm \\
0.29^{b}\end{array}$ & $\begin{array}{l}45.10 \\
\pm 5.79^{\mathrm{a}}\end{array}$ & $\begin{array}{l}1.24 \\
\pm \\
0.51^{\mathrm{a}}\end{array}$ & $\begin{array}{l}0.05 \\
\pm \\
0.04^{\mathrm{b}}\end{array}$ & $\begin{array}{l}49.2 \\
\pm \\
26.4^{\mathrm{a}}\end{array}$ & $\begin{array}{l}3531.0 \\
\pm \\
3213.9^{a}\end{array}$ & $\begin{array}{l}62.4 \\
\pm \\
26.2^{a}\end{array}$ & $3531: 62: 1$ \\
\hline & hemic $\mathrm{H}$. & $\begin{array}{l}82.72 \\
\pm \\
4.74^{\mathrm{a}}\end{array}$ & $\begin{array}{l}4.74 \\
\pm \\
0.36^{\mathrm{ab}}\end{array}$ & $\begin{array}{l}4.03 \\
\pm \\
0.57^{b}\end{array}$ & $\begin{array}{l}33.34 \\
\pm \\
11.63^{\mathrm{ab}}\end{array}$ & $\begin{array}{l}1.42 \\
\pm \\
0.46^{\mathrm{a}}\end{array}$ & $\begin{array}{l}0.06 \\
\pm \\
0.01^{\mathrm{b}}\end{array}$ & $\begin{array}{l}28.5 \\
\pm \\
11.7^{\mathrm{a}}\end{array}$ & $\begin{array}{l}1376.9 \\
\pm \\
546.6^{\mathrm{ab}}\end{array}$ & $\begin{array}{l}49.7 \\
\pm \\
16.3^{\mathrm{a}}\end{array}$ & 1377:50:1 \\
\hline & sapric $\mathrm{H}$. & $\begin{array}{l}80.54 \\
\pm \\
7.11^{\mathrm{a}}\end{array}$ & $\begin{array}{l}6.09 \\
\pm \\
0.64^{\mathrm{a}}\end{array}$ & $\begin{array}{l}5.53 \\
\pm \\
0.65^{\mathrm{a}}\end{array}$ & $\begin{array}{l}30.47 \\
\pm \\
9.18^{\mathrm{ab}}\end{array}$ & $\begin{array}{l}1.63 \\
\pm \\
0.46^{\mathrm{a}}\end{array}$ & $\begin{array}{l}0.13 \\
\pm \\
0.02^{\mathrm{a}}\end{array}$ & $\begin{array}{l}23.1 \\
\pm \\
10.0^{\mathrm{a}}\end{array}$ & $\begin{array}{l}582.7^{ \pm} \\
134.8^{\mathrm{b}}\end{array}$ & $\begin{array}{l}27.1 \\
\pm 7.8^{\mathrm{a}}\end{array}$ & $583: 27: 1$ \\
\hline
\end{tabular}

The average lowland Histosols' $\mathrm{C} / \mathrm{N}$ ratio ranged between 18.8 and 41.6, while mountain Histosols ranged between 23.1 and 49.2 (Table 2). Sapric Histosols had a low $\mathrm{C} / \mathrm{N}$ ratio regardless of its sample location. It also had a significantly lower $\mathrm{C} / \mathrm{P}$ ratio regardless of location. The C/P ratio was highest in the fibric Histosols (Table 2), while we found a significantly lower N/P ratio in sapric Histosols. These results demonstrate the significant differences in the concentrations of $\mathrm{C}, \mathrm{N}$ and $\mathrm{P}$, as well as in the ratios of $\mathrm{C} / \mathrm{N} / \mathrm{P}$ between different types of Histosols. In the current study, we found higher C/N/P ratio values in the fibric Histosols, regardless of localisation. In the case of lowland Histosols, the C/N/P ratio ranged between 797/42/1 and 2264/56/1, while the mountain Histosols had the lowest ratios, with the lowest at 583/27/1, and the highest at 3531/62/1. In the case of the sapric Histosols, the lowest C/N/P ratio was recorded regardless of localisation. Meanwhile, we also noted a reduction of the C/N/P ratio for the Histosols drainic (Table 2). The statistical analysis indicates a strong relationship between the $\mathrm{C} / \mathrm{P}$ ratio and the $\mathrm{pH}$ of the 
studied soils ( $r=-0.538)$ (Fig. 2). A positive correlation of $\mathrm{C} / \mathrm{N}$ with $\mathrm{C} / \mathrm{P}$ in Histosols was also determined $(r=0.695)($ Fig. 2). The strong influence of the type of Histosols on the $\mathrm{C} / \mathrm{N}, \mathrm{C} / \mathrm{P}$ and N/P ratios was confirmed by GLM analysis (Table 3 ). Additionally, we confirmed the importance of the localisation of Histosols for the N/P ratio.

The current research confirms the importance of the type of Histosols on the accumulation of $\mathrm{C}, \mathrm{N}$ and $\mathrm{P}$. Regardless of the location of the research plots, a significantly lower $\mathrm{C}$ stock was recorded in the Histosols drainic, while the highest was found in the sapric Histosols (Fig. 3). The results for the sapric Histosols also indicated significantly higher nitrogen and phosphorus stock. The lowest accumulation of $\mathrm{N}$ and $\mathrm{P}$ were found in the fibric and Histosols drainic (Figs. 4 and 5). The GLM analysis confirmed that the Histosol type was the strongest factor in shaping the $\mathrm{C}, \mathrm{N}$ and $\mathrm{P}$ stock. With regard to the P stock, the importance of location and moisture content was also confirmed (Table 4). A projection of the variables on the factor plane clearly demonstrated the relationship of Histosol types with their properties (Fig. 6). Moreover, the PCA analysis confirmed that the highest C/N, C/P and N/P ratios were associated with fibric Histosols, while sapric Histosols had the highest $\mathrm{pH}$ and $\mathrm{C}, \mathrm{N}$ and $\mathrm{P}$ reserves. All of the types of Histosols tested differed in moisture levels (Fig. 6).

Table 3 Summary of general linear model (GLM) analysis of the effect of Histosol type, localization and moisture for the C/N, C/P and N/P

ratio

\begin{tabular}{|lllllll|}
\hline & C/N & \multicolumn{3}{c}{ C/P } & \multicolumn{3}{c|}{ N/P } \\
\hline & $\mathrm{F}$ & $p$ value & $\mathrm{F}$ & $p$ value & $\mathrm{F}$ & $p$ value \\
\hline Typ of Histosol & 23.862 & $\mathbf{0 . 0 0 0 0}$ & 11.682 & $\mathbf{0 . 0 0 0 0}$ & 8.067 & $\mathbf{0 . 0 0 0 1}$ \\
\hline Localization & 0.493 & 0.4840 & 1.979 & 0.1624 & 7.769 & $\mathbf{0 . 0 0 6 3}$ \\
\hline Moisture & 0.026 & 0.8727 & 0.612 & 0.4358 & 2.660 & 0.1059 \\
\hline
\end{tabular}

Significance effect $(P<.05)$ are shown in bold

Table 4

Summary of general linear model (GLM) analysis of the effect of Histosol type, localization and moisture on carbon $\left(\mathrm{S}_{\mathrm{C}}\right)$, nitrogen $\left(\mathrm{S}_{\mathrm{N}}\right)$ and phosphorus $\left(\mathrm{S}_{\mathrm{P}}\right)$

\begin{tabular}{|lllllll|}
\hline \multicolumn{1}{|c}{$\mathrm{S}_{\mathrm{C}}$} & \multicolumn{3}{c}{$\mathrm{S}_{\mathrm{N}}$} & \multicolumn{3}{c|}{$\mathrm{S}_{\mathrm{P}}$} \\
\hline & $\mathrm{F}$ & $p$ value & $\mathrm{F}$ & $p$ value & $\mathrm{F}$ & $p$ value \\
\hline Typ of Histosol & 3.860 & $\mathbf{0 . 0 1 1 5}$ & 18.628 & $\mathbf{0 . 0 0 0 0}$ & 10.083 & $\mathbf{0 . 0 0 0 0}$ \\
\hline Localization & 1.438 & 0.2331 & 1.015 & 0.3160 & 5.053 & $\mathbf{0 . 0 2 6 7}$ \\
\hline Moisture & 0.756 & 0.3866 & 0.224 & 0.6372 & 5.368 & $\mathbf{0 . 0 2 2 4}$ \\
\hline Significance effect $(\mathrm{P}<.05)$ are shown in bold & & & \\
\hline
\end{tabular}

\section{Discussion}

The Histosol subtypes we examined in the current study are characterised by different C/N, C/P and N/P ratios. The lowest ratios were found in the sapric Histosols, which also had the highest $\mathrm{pH}$ and a significantly higher content of $\mathrm{N}$ and $\mathrm{P}$. The low $\mathrm{C} / \mathrm{N}$ ratio reflects a more intensive decomposition of soil organic matter as well as the quality of this organic matter and the rates of microbial transformation processes (Santos et al. 2020). The low C/P and N/P ratio in sapric Histosols confirms the increase of nutrients in soil organic matter in relation to the $\mathrm{C}$ content. Fibric Histosols and hemic Histosols are characterised by high $\mathrm{C} / \mathrm{N}, \mathrm{C} / \mathrm{P}$ and N/P ratios. In the case of the dehydrated Histosols drainic, the C/N, C/P and N/P ratios were lower than those of the fibric and hemic Histosols. In addition, we found that the conditions under which soils are formed - wet and dry conditions or alternating dry and wet conditions - are important for shaping the $\mathrm{C} / \mathrm{N}, \mathrm{C} / \mathrm{P}$ and N/P ratios. The rate of decomposition, which depends on 
microorganism activity, is related to moisture levels (Davidson and Janssens 2006; Qi et al. 2013). In fact, soil moisture is the principal environmental factor that regulates SOM decomposition (Wang et al. 2016). Dehydrated soils lose $C$ at a faster rate, and therefore lower $\mathrm{C} / \mathrm{N}$ or C/P ratios can be expected (Leifeld et al. 2020). Drainage of organic soils have been found to increase organic carbon mineralisation and $\mathrm{CO}_{2}$ emissions (Lal et al. 2004; Wang et al. 2017), and in the case of the Histosols drainic, we recorded significantly lower organic carbon content. Phosphorus also plays a role in shaping the rate of decomposition of organic matter, and organic matter, being poorer in nitrogen and phosphorus, is much more resistant to bacterial degradation (Wetzel, 2001). The phosphorus accumulation and the $C / P$ ratio values we are reporting here are characteristic of dehydrated Histosols (Worrall et al. 2016; Becher et al. 2020). Meanwhile, the relative importance of the P content depends on the amounts of carbon, lignin, cellulose, polyphenol and nitrogen; their ratios to $P$ are also considered predictors of decomposition (Baggie et al. 2004). The Histosols we tested for this research differed in C/N/P stoichiometry, with the lowest (583/27/1) found in the sapric Histosols. In this type of Histosols, the C/N/P stoichiometry is similar to mineral soils. As Cleveland and Liptzin (2007) noted, the C/N/P stoichiometry in soil amounts to 186/13/1. Moreover, Kirkby et al. (2011) suggested that mineral soil is characterised by an even narrower $\mathrm{C} / \mathrm{N} / \mathrm{P} / \mathrm{S}$ stoichiometry (52/5/1/1). The low values of the $\mathrm{C} / \mathrm{N} / \mathrm{P}$ stoichiometry for the sapric Histosols are due to nutrient availability - nitrogen and phosphorus, especially. Fibric Histosols and hemic Histosols had lower levels of components, which results in higher $\mathrm{C} / \mathrm{N} / \mathrm{P}$ stoichiometry values. In the case of dehydrated Histosols drainic, we noted a decrease in C/N/P stoichiometry, which is directly related to the increased mineralisation of organic matter. In our research, soils with high C/N/P stoichiometry are characterised by significantly lower phosphorus content, which may limit the growth of microorganisms, and consequently, the microbial decomposition of organic matter. Research has shown that rates of mineralisation and immobilisation are related to residue-P content and the C/P ratio (Seggar et al. 1998). In addition, the critical content of a residue above which $P$ is not immobilised has been reported to be $0.2-0.3 \%$ (Baggia et al. 2004). Fibric and hemic Histosols had the widest C/N/P stoichiometry, which can be explained by their high moisture and acidity, both of which limit decomposition rates.

The relationships described above apply to Histosols from lowland and mountain areas. We found that the C/N/P stoichiometry was lowest in the sapric Histosols and highest in the fibric Histosols for samples from both the mountains and the lowlands. In the mountains as well as in the lowlands, the drainage effect of Histosols can be seen through the reduced C/N, C/P and N/P ratios, which are the result of soil organic matter mineralisation. In mountainous areas characterised by lower temperatures and higher rainfall, Histosols are also exposed to periodical drying, which leads to an increase in their hydrophobicity, and consequently, to a change in chemical properties. Furthermore, Histosols' hydrophobicity is enhanced by poorly decomposed peat-forming plant fibres ( achacz et al. 2009; Kalisz et al. 2015; Glina et al. 2016). Changes in peatland conditions as a result of groundwater oscillations activate the transformation of peat in moorsh, which leads to changes in its structure through the modification of hydrophilic properties into hydrophobic ones (Szajdak et al. 2020). Changes in peat structure during wetting and drying influences the heterogeneous distributions of microbial habitats and activity in peat soil and plays a crucial role in the emission and sequestration of $\mathrm{CO}_{2}$ and $\mathrm{CH}_{4}$ fluxes in peatlands (Rezanezhad et al. 2016).

Any changes in temperature, moisture or nutrient availability due to climate change or land management could have significant effects on carbon fluxes and sequestration rates of carbon in the forest ecosystem (Keith et al. 1997). The current research proves the effect of dehydration on the carbon stock, and to a lesser extent, on the nitrogen stock. Regardless of the sample location, we recorded significantly lower carbon stock in the drainic Histosols.

Research has shown that dehydration, in addition to the influence of mineralisation, affects the diversity of plants; in fact, dehydration causes the disappearance of peat-forming plants. In our research, Histosols drainic were associated with vegetation typical of fresh and wet habitats (i.e. Calamagrostis arundinacea, Molinia caerulea, Dryopteris dilatata), and did not contain peatforming plants. According to Weissert and Disney (2013), sphagnum is important for the formation of deep peat and could potentially be used to assess the quality of peatlands. Water level shifts drive vegetation change, particularly because woody plants are generally more productive under drawdown conditions, while sphagnum mosses are favoured in wetter, or even flooded, conditions (Zhong et al. 2020). In the case of the Histosols drainic, we recorded a 50\% lower carbon stock compared to other types of Histosols. In Histosols drainic, the $\mathrm{C}$ reserve was about $400 \mathrm{Mg} \mathrm{ha}^{-1}$, regardless of the sample location. The remaining types of

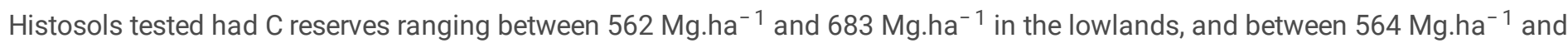
$738 \mathrm{Mg} \cdot \mathrm{ha}^{-1}$ in the mountains. 


\section{Conclusions}

The current research confirms the problem of Histosol dehydration in forest ecosystems, in both the lowlands and in the mountains. The dehydration effect is shown in the $\mathrm{C} / \mathrm{N} / \mathrm{P}$ stoichiometry, as our results show that Histosol dehydration leads to a narrowing of the C/N/P stoichiometry. This is directly related to the intensification of the organic matter mineralisation process and, as a result, the loss of organic carbon. The narrower $\mathrm{C} / \mathrm{N} / \mathrm{P}$ stoichiometry in Histosols drainic is the result of an improvement in the ratio of $\mathrm{N}$ and $\mathrm{P}$ to the $\mathrm{C}$ content. As a result of dehydration, the total $\mathrm{C}$ store in Histosols drainic is reduced by $50 \%$. Our results show that large $\mathrm{C}$ losses occur as a result of Histosol dehydration and indicate the need for their protection. These results also demonstrate the importance of maintaining an appropriate water level in peatlands, because rising water tables maintain anaerobic conditions and enhance the role of peatlands as a C sink. In order to maintain adequate carbon storage in Histosols, we must strive to maintain a balance between primary productivity and decomposition. Good practice and careful land use management is essential if we are to minimise the negative effects of climate change in Histosols.

\section{Declarations}

\section{Acknowledgments}

This work was supported by the Ministry of Science and Higher Education of the Republic of Poland (SUB/040012/D019; A425, A428).

\section{Authors' contributions}

$\mathrm{JL}, \mathrm{EB}$ designed the experiment and implemented the study. All authors analysed the results and contributed to the manuscript writing and editing. All authors read and approved the final manuscript.

\section{Availability of data and materials}

Data available on request from the authors

\section{Ethics approval and consent to participate}

The subject has no ethic risk.

\section{Consent for publication}

Not applicable.

\section{Competing interests}

The authors declare that they have no competing interests.

\section{References}

Baggie I, Rowell DL, Robinson JS, Warren GP (2004) Decomposition and phosphorus release from organic residues as affected by residue quality and added inorganic phosphorus. Agrofor Syst 63:125-131.

Becher M, Pakuła K, Jaremko D (2020) Phosphorus accumulation in the dehydrated peat soils of the Liwiec river valley. J Ecol Eng 21:213-220.

Błońska E, Lasota J (2017) Soil Organic Matter Accumulation and Carbon Fractions along a Moisture Gradient of Forest Soils. Forests 8:448.

Cleveland CC, Liptzin D (2007) C/N/P stoichiometry in soil: is there a "Redfield ratio" for the microbial biomass? Biogeochemistry 85:235-252. 
Dorrepaal E, Sylvia T, van Logtestijn RSP, Swart E, Van de Weg MJ, Callaghan TV, Aerts R (2009) Carbon respiration from subsurface peat accelerated by climate warming in the subarctic. Nature 460:616-619.

Fang Z, Li DD, Jiao F, Yao J, Du HT (2019) The Latitudinal Patterns of Leaf and Soil C:N:PStoichiometry in the Loess Plateau of China. Front Plant Sci 10:85.

Farquhar GD, Fasham MJR, Goulden ML, Heimann M, Jaramillo VJ, Kheshgi HS, Le Quere C, Scholes RJ, Wallace DWR (2001) Climate change 2001: The Scientific Basis IPCC. Chapter 3. The Carbon Cycle and Atmospheric Carbon Dioxide. Cambridge University Press, Cambridge. 183-237.

Fornara DA, Steinbeiss S, McNamara NP, Gleixner G, Oakley S, Poulton PR, Macdonald AJ, Bardgett RD (2011) Increases in soil organic carbon sequesttration can reduce the global warming potential of long-term liming to permanent grassland. Global Change Biology 17:1925-1934.

Glina B, Bogacz A, Gulyás M, Zawieja B, Gajeski P, Kaczmarek Z (2016) The effect of long-term for estry drainage on the current state of peatland soils: A case study from the Central Sudetes, SW Poland. Mires and Peat 18:1-11.

Huang J, Wang P, Niu Y, Yu H, Ma F, Xiao G, Xu X (2018_ Changes in C:N:P stoichiometry modify N and P conservation strategies of a desert steppe species Glycyrrhiza uralensis. Sci Rep 8:12668.

Ilnicki P (2002) Peatlands and peat. Agricultural Academy Press, Poznań, 606 pp.

Joosten H (2009) The Global Peatland CO2Picture: Peatland Status and DrainageRelated Emissions in All Countries of the World. Wetlands International, Netherlands

Kabała C, Marzec M (2016) Problemy diagnozowania typów siedliskowych lasu oraz określania stanu siedliska w lasach na terenach odwodnionych. [w:] Siedliska leśne zmienione i zniekształcone. Zielony R. (red.). CILP, Warszawa, s: 79-88.

Kalisz B, Łachacz A, Głażewski R (2015) Effects of peat drainage on labile organic carbon and water repellency in NE Poland. Turk J Agric For 39:20-27.

Keith H, Jacobsen KL, Raison RJ (1997) Effects of soil phosphorus availability, temperature and moisture on soil respiration in Eucalyphus peuciflora forest. Plant Soil 190:127-141.

Kirkby CA, Kirkegaard JA, Richardson AE, Wade LJ, Blanchard C, Baten G (2011) Stable soil organic matter: a comparison of C/N/P:S ratios in Australian and other world soils. Geoderma 162:197-208.

Kondras M, Czępińska-Kamińska D, Sienicka P, Otręba A, Torzewski K, Oktaba L (2012) Zapas węgla organicznego w glebach leśnych zespołu kontynentalnego boru mieszanego świeżego w Kampinoskim Parku Narodowym. Soil Sci Annu 63:26-33.

Lal R, Grifin M, Apt J, Lave L, Morgan MG (2004) Managing soil carbon. Science 304:3

Leifeld J, Klein K, Wüst-Gallet C (2020) Soil organic matter stoichiometry as indicator for peatland degradation. Sci Rep 10:7634. Łachacz A, Nitkiewicz M, Kalisz B (2009) Water repellency of post-boggy soils with a various content of organic matter. Biologia 64(3):634-638.

Qi XJ, Lv JW, Wang ES, Chen X (2013) Changes in enzyme activities and soil properties of different altitudes of Chang-bai Mountain, China in the rhizosphere and non-rhizosphere soils of Rhododendron chrysanthum Pall. Res J Biotechnol 8:71-78.

Ostrowska A, Gawliński S, Szczubiałka Z (1991) Methods of Analysis and Assessment of Soil and Plant Properties. Institute of Environmental Protection, Warszawa.

Rezanezhad F, Price JS, Quinton WL, Lennartz B, Milojevic T, Van Cappellen P (2016) Structure of peat soils and implications for water storage,flow and solutetransport: A review update for geochemists. Chem Geol 429:75-84. 
Santos OAQ, Silva Neto EC, Garcia AC, Fagundes HS, Diniz YVFG, Ferreira R, Pereira MG (2020) Impact of land use on Histosols properties in urban agriculture ecosystems of Rio de Janeiro, Brazil. Rev Bras Cienc Solo 44:e0200041.

Slepetiene A, Amaleviciute-Volunge K, Slepetys J, Liaudanskiene I, Volungevicius J (2018) The Status of Pachiterric Histosol Properties as Influenced by Different Land Use, Peat, Bülent Topcuoğlu and Metin Turan, IntechOpen, DOI:

10.5772/intechopen.74151.

Sterner RW, Elser JJ (2002) Ecological Stoichiometry: The Biology of Elements from Molecules to the Biosphere. New Jersey: Princeton University Press.

Szajdak LW, Jezierski A, Wagner K, Meysner T, Szczepański M (2020) Influence of drainage on peat organic matter: implications for development, stability and transformation. Molecules 25:2587.

Tipping E, Somerville CJ, Luster J (2016) The C/N/P:S stochiometry of soil organic matter. Biogeochemistry 130:117-131.

Worrall F, Moody CS, Clay GD, Burt T, Rose R (2016) The total phosphorus budget of a peat-covered catchment. J Geophys Res Biogeosci 121:1814-1828.

Zhang Z, Xue Z, Lyu X, Tong S, Jiang M (2017) Scaling of soil carbon, nitrogen, phosphorus and C/N/P ratio patterns in peatlands of China. Chinese Geogr Sci 27(4):507-515.

Zhong Y, Jiang M, Middleton BA (2020) Effect of water level alteration on carbon cycling in peatlands. Ecosystem Health and Sustainability 6:1-29.

Zwydak M, Brożek S, Lasota J, Małek S (2008) Reserve of Organic Carbon in Forest Soils of Lowlands in Poland. Polish J Environ Stud 17:632-637.

\section{Figures}




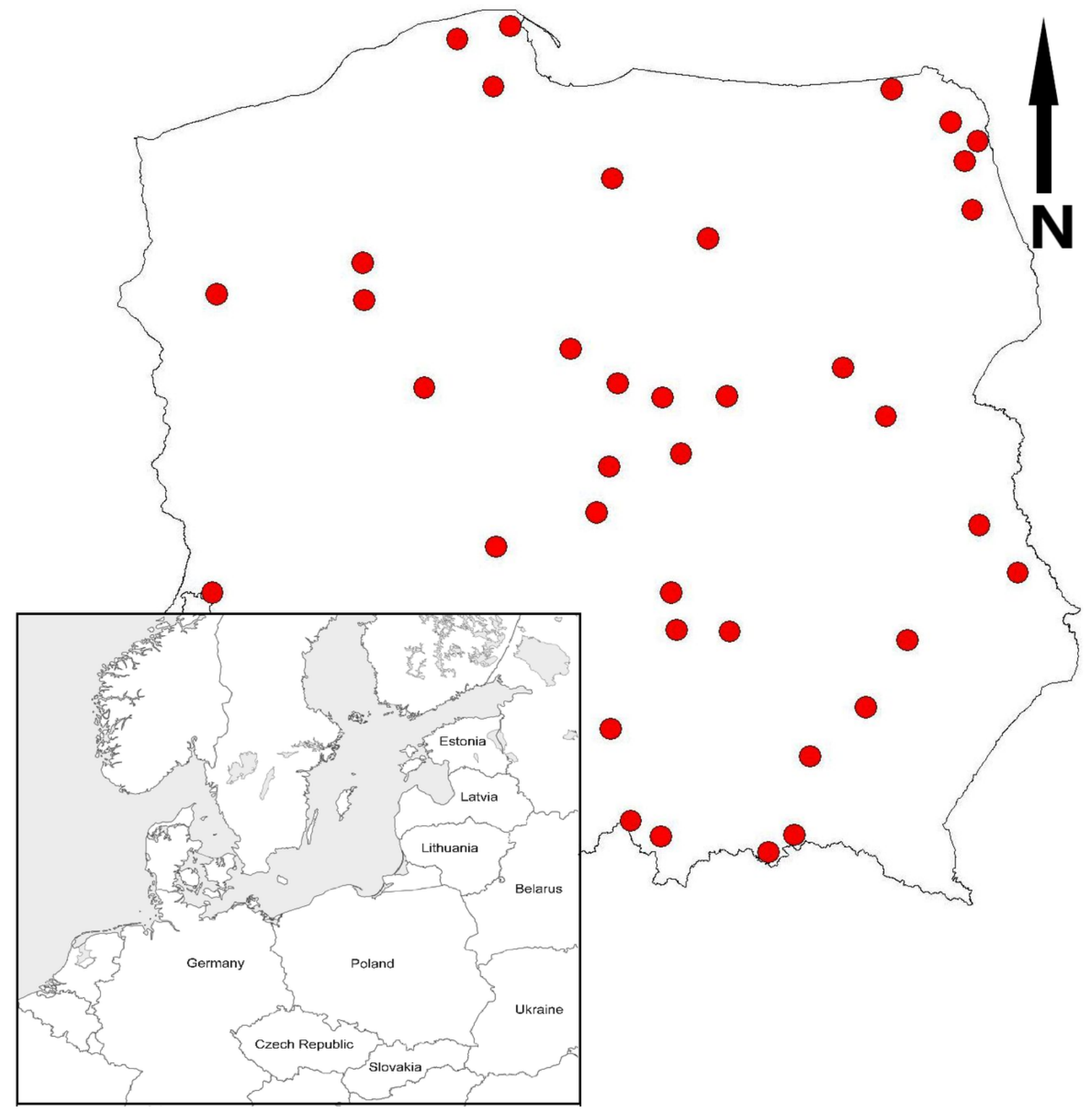

Figure 1

Localization of study plots in Poland 

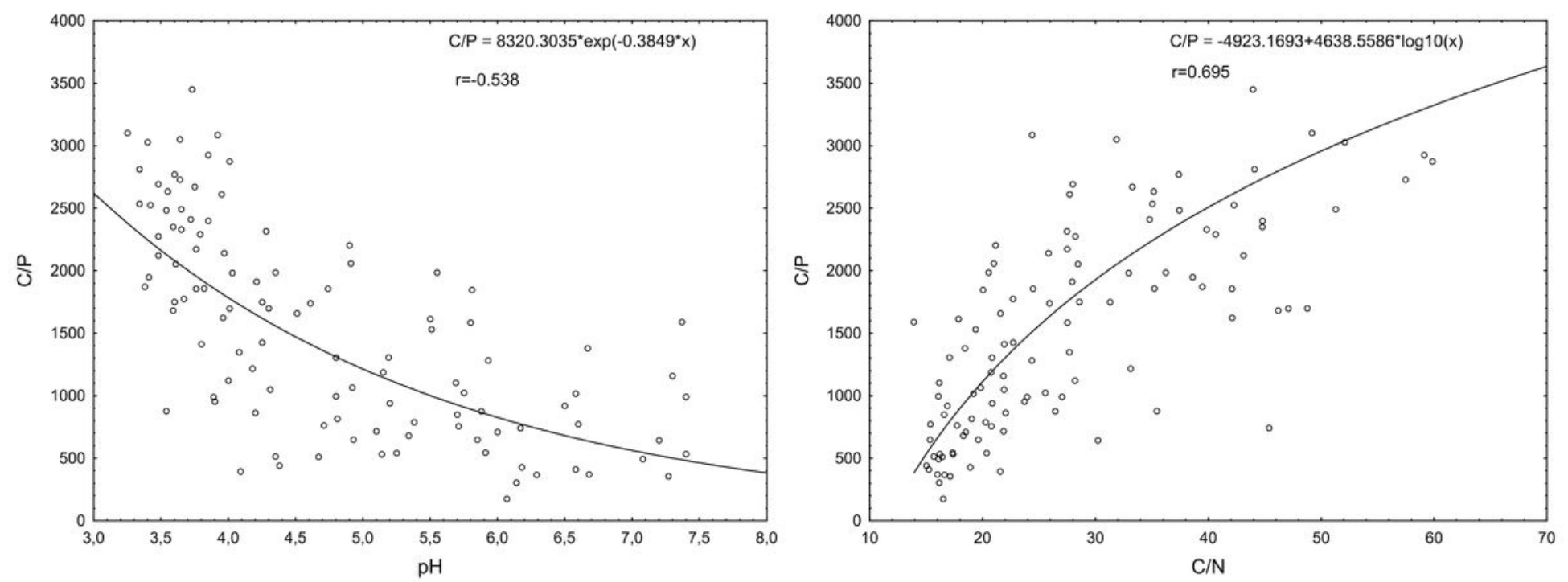

\section{Figure 2}

Relationships between $\mathrm{C} / \mathrm{P}$ ration with $\mathrm{pH}$ and $\mathrm{C} / \mathrm{N}$ ratio
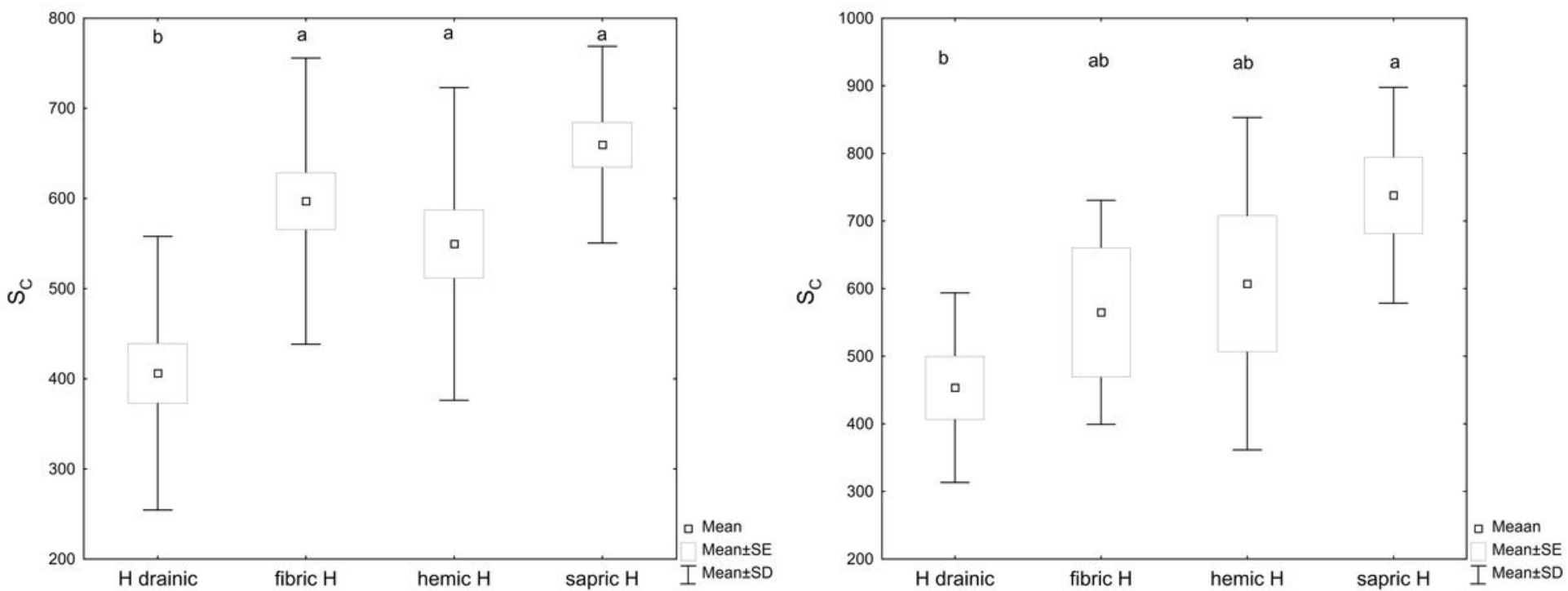

Figure 3

Carbon stock in different type of Histosol (on the left lowlands, on the right mountains) 

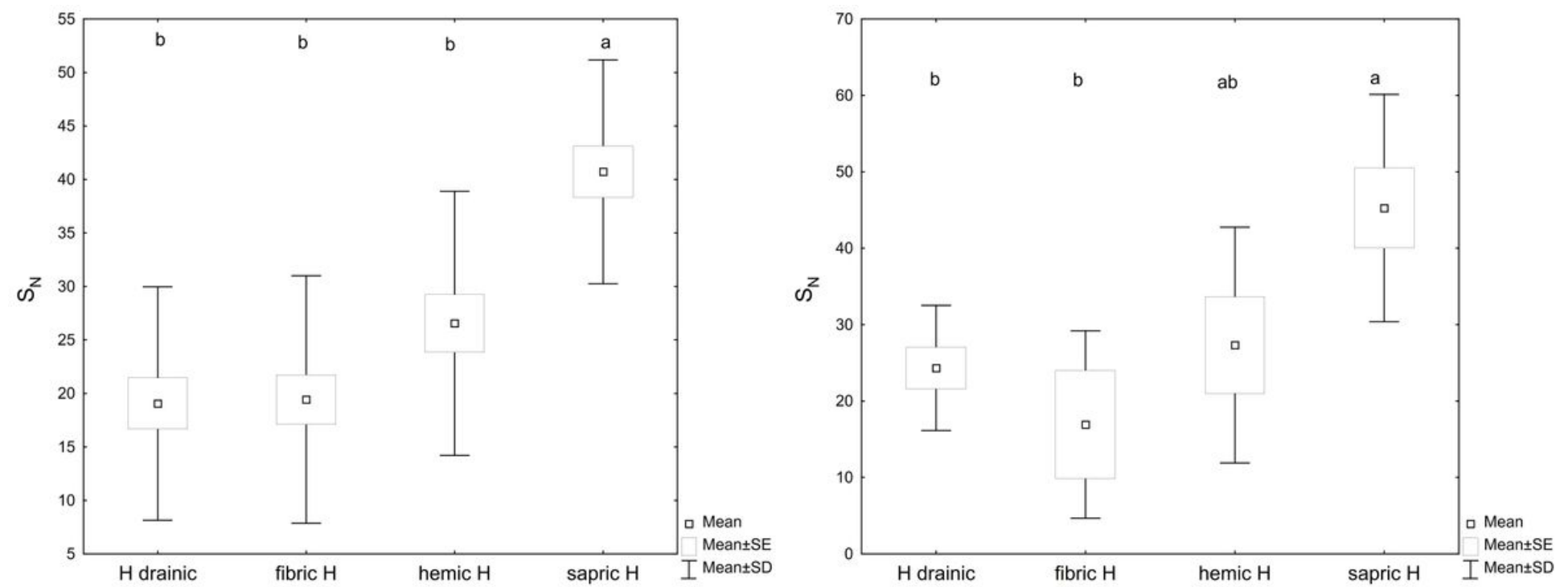

\section{Figure 4}

Nitrogen stock in different type of Histosol (on the left lowlands, on the right mountains)
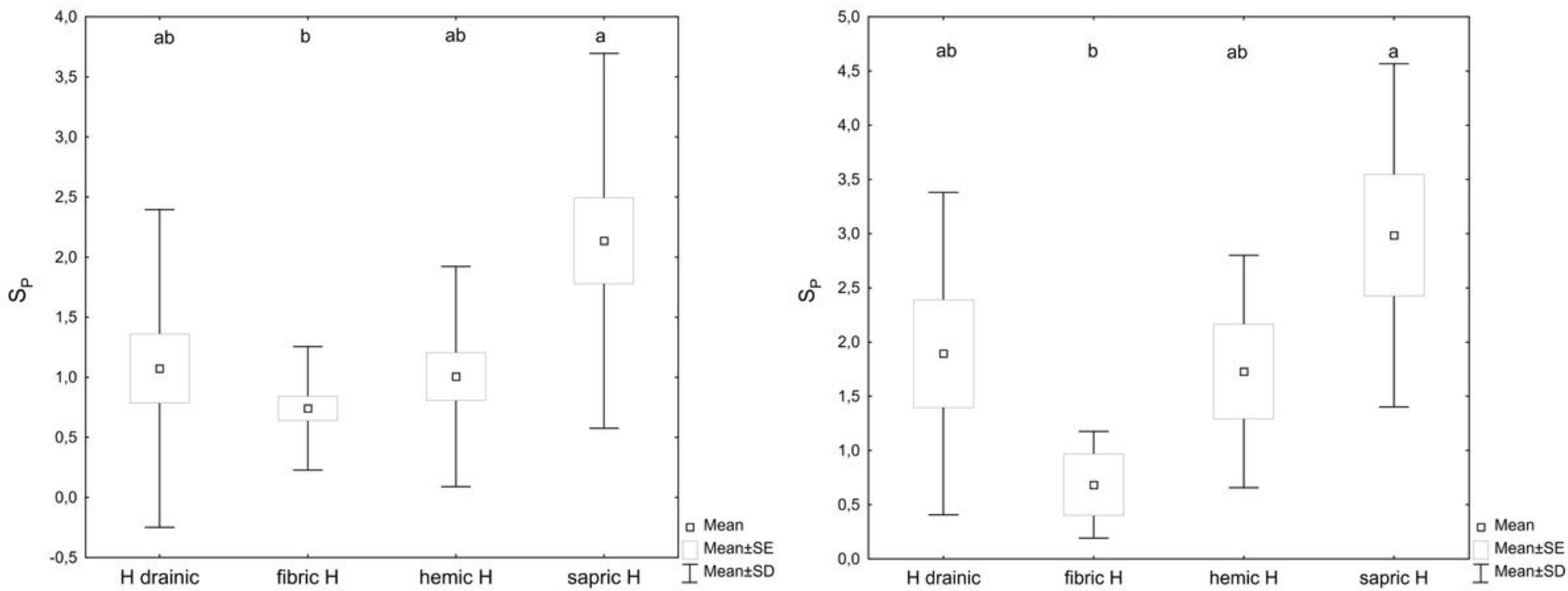

Figure 5

Phosphorus stock in different type of Histosol (on the left lowlands, on the right mountains) 


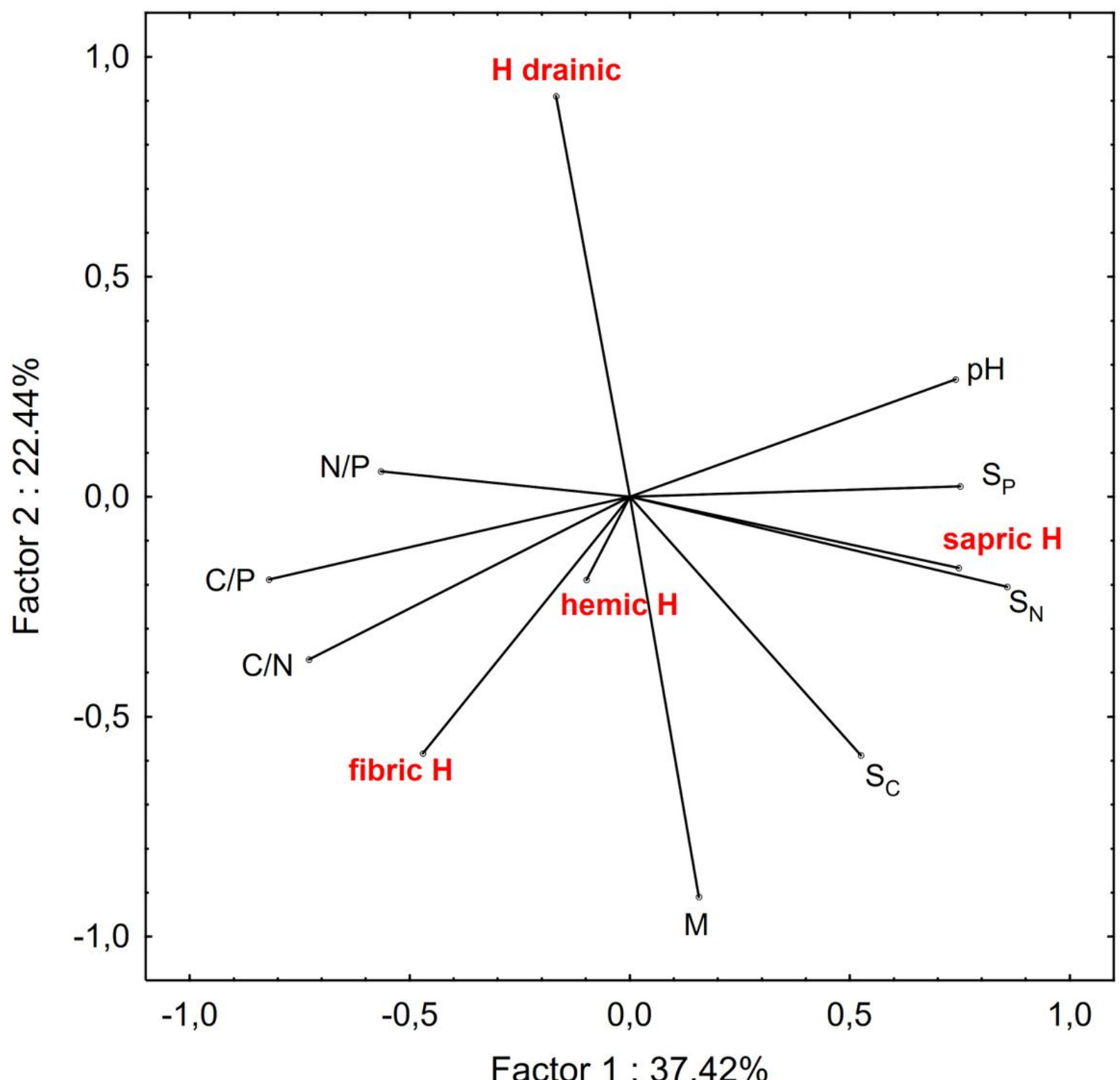

Figure 6

The projection of variables on a plane of the first and second PCA factor 